\title{
Melankolikerne har hatt årsmøte
}

\author{
Melankolske overlegers landslag - forkortet MOLL - har hatt sitt årlige møte. Det ble en trist affære.
}

Årsmøtene holdes hjemme hos et av medlemmene, som inviterer på middag. Ubegrenset taletid gjør at middagen blir lang. Hvert av de fire medlemmene kommer med melankolske betraktninger over året som er gått - eller over livet generelt.

MOLL har strenge opptakskrav. En kollega ringte nylig formannen, hun ønsket å bli medlem. Det vil si - hun ønsket å etablere en subgruppe, nemlig ekstremt melankolske overlegers landslag, forkortet e-MOLL. I løpet av samtalen ble det klart at vedkommende ikke fylte kravene. Hun virket rett og slett for lystig.

Vi dvelte $\mathrm{i}$ år ved uttrykket «melankoli». Det stammer fra den gang man mente all sykdom skyldtes manglende balanse mellom de fire kroppsvæsker blod, slim, svart og gul galle (humoralpatologien). Ved melankoli var det en overvekt av svart (melanos) galle (koli). Relasjonen mellom sinnsstemning og galle ble grundig debattert. Koleriske personer ble trukket frem. Kanskje er gallen opphavet til svart humor - en humorform medlemmene fant tiltrekkende.

Et medlem hevdet at etter mange år i norsk helsevesen kom den melankolske grunnstemningen av seg selv.

Siden medlemmene begynner å eldes, kom årets møte til å stå i ettertankens tegn. Hvordan hadde vi forvaltet våre sparsomme pund? Et medlem hevdet hans liv så ut til å bli et trist kapittel i den store glemmeboken. En annen, som nettopp hadde fylt 65 år, siterte Knut Hamsun:

Nå har jeg bare den heslige alderdommen å se frem til.

En mager trøst var at det er først når man passerer 80 år at man rykker opp i avgangsklassen.
Som alltid ble det etter hvert mye lyrikk. Medlemmene har alle vokst opp på Østlandet. Her har den mørke og dystre granskogen satt sitt varige preg på våre sinn. Eller, som Jørgen Moe så treffende sier det: Akk, skogen og fjellvannet hadde i mitt sinn

for første gang suset sin vemodstanke inn - og siden jeg glemmer den vel aldri.

Et av medlemmene er kjenner av skogens dikter par exellence, Hans Børli (1). Intet MOLL-møte uten et Børli-dikt! I år resiterte han blant annet:

A vare menneske er en sjukdom.

Helbredelse er umulig,

men all vår streben består $i$

a finne et smertestillende middel.

Ensomhet er melankoliens nære slektning. Et av medlemmene mente han til tider var mer ensom enn en kråkebolle på Dovre.

Han følte seg i slekt med Stavanger-poeten Sigbjørn Obstfelder, han som mente han var havnet på feil klode:

Her er så underligt.

Eller, som han sier et annet sted:

Fødes, lide, visne var livet.

André Bjerke fikk også en plass på årets møte: Lev, lev lille gutt.

Livet er en drøm.

Før du aner er det slutt, snart er alle broer brutt. Alle er alene.

Vi gjorde også en visitt innom dikterhøvdingen på Aulestad:

Hver gledesstund du fikk på jord, betales må med sorg.
Et annet Bjørnson-sitat var riktignok noe forvrengt:

Are det evige vemod i livet - og alt som er tapt.

Også tristessene til Nils-Fredrik Nielsen er populære:

Det er aldri for sent å gi opp.

Det er aldri for grått til å vare sant.

Han var så klar at han var deprimert helt til det siste.

Et av medlemmene fortalte han hadde vært alvorlig syk siden sist (trolig en langvarig forkjølelse). Han hevdet han hadde vært så dårlig at han «ikke engang orket å synge på siste verset».

Han fikk de andre medlemmenes fulle sympati og støtte.

Med en ukuelig pessimisme ble årets møte avsluttet. Verten ble behørig takket for en mismodig kveld.

\section{Karl O. Nakken}

formann

\section{Litteratur}

1. Martinsen EW. Å finne små nok ord til store nok følelser. Tidsskr Nor Lægeforen 2001; 121: 3390. 